\title{
Spatial Deictics and Translational Implicitation: Evidence from a Corpus-based Analysis of English and Lithuanian Fictional Discourse
}

\author{
Darija Bartkute \\ Education Academy, Vytautas Magnus University, Vilnius, Lithuania
}

Email address:

darija.bartkute@vdu.lt

To cite this article:

Darija Bartkute. Spatial Deictics and Translational Implicitation: Evidence from a Corpus-based Analysis of English and Lithuanian Fictional Discourse. International Journal of Language and Linguistics. Vol. 8, No. 5, 2020, pp. 229-239. doi: 10.11648/j.ij11.20200805.15

Received: September 1, 2020; Accepted: September 21, 2020; Published: October 7, 2020

\begin{abstract}
Based on the typology of universal uses of demonstratives and presumption of translational explicitation, this paper compares and contrasts demonstratives from a semantic and pragmatic perspective. It aims to identify the translation correspondences of the English demonstratives in Lithuanian and contrast their usage in a comparable corpus to determine the cross-linguistic differences resulting from unequal distribution of lexical correspondences in both languages. This paper analyses a self-compiled parallel corpus and comparable corpus extracted from the Corpus of the Contemporary Lithuanian Language to examine the translation effects at the discourse pragmatic level in the rendition of spatial deixis. The translation correspondences highlight the key role of optional implicitation caused by the availability of contextual variants in the textual uses of demonstratives in Lithuanian. The translation results also reveal that the Lithuanian three-way system of demonstratives shows signs of reduction to a two-way system, as there is an analogous distribution between the English distal demonstrative and the neutral (medial) demonstrative in Lithuanian. A comparison of original texts points to important crosslinguistic differences determined by discourse-related factors, such as higher frequencies of demonstratives in the anaphoric and recognitional functions in Lithuanian texts, which is largely determined by the unmarked status of the neutral (medial) demonstrative. While its article-like status is gaining increasing attention in the literature, the present results indicate that the (neutral) medial demonstrative is an optional indicator of identification that occurs as a stylistic and text-building preference and contributes to greater textual pragmatic explicitness of Lithuanian fiction texts.
\end{abstract}

Keywords: Spatial Deixis, Three-way System of Demonstratives, Optional Implicitation, English/Lithuanian

\section{Introduction}

This paper presents a corpus-based study of the English and Lithuanian demonstratives that focuses on crosslinguistic correspondence at the semantic and pragmatic levels. The analysis is based on a universal typology of uses of demonstratives $[16,26]$ and translational explicitation/implicitation hypothesis explicated by Klaudy and Károly [32]. It also incorporates insights into the proximity/distality distinction in the three-way system of demonstratives in Lithuanian and investigates the causes of unequal distribution of demonstratives drawing on a comparable corpus of both languages. The research questions aim to explain how the semantics of space deictics is interrelated with their pragmatic meanings and how the expression of space deixis determines the textual pragmatic implicitness/explicitness in typologically different languages.

Contemporary cross-linguistic research emphasizes the pragmatic functions of demonstratives [16, 17, 26, 39, 56]. The semantic and textual characteristics of demonstratives are largely viewed in respect to the dichotomy between proximity and distality in the Lithuanian reference works. This paper assumes that the distinction between proximity and distality is less distinctive in the actual usage of demonstratives and is typical in limited contexts of usage. The analysis proceeds from the assumption that the semantic dichotomy of proximity and distality is not neutralized in Lithuanian, but members of the opposition are also characterized by greater or lesser variability in their pragmatic functions. The description of the usage of 
demonstratives in Lithuanian should be situated within a larger typological classification.

The research problem also arises from the theoretical contradiction between the pragmatically implicit/explicit nature of discourse caused by the expression of deixis in pairs of languages as representatives of different communicative norms $[6-8,24,25,33,46,47]$. The assumption is made that the deictic centre is less actualized in Lithuanian due to the abundance of facultative correspondences in the translated text, which suggests that Lithuanian uses different text-building strategies and has a different distribution of demonstratives in narrative texts. Corpus triangulation methodology is assumed to reliably account for the textual pragmatic explicitness/implicitness of English and Lithuanian.

Using a self-compiled English-Lithuanian parallel corpus of contemporary fiction texts, a search for demonstratives this and that is performed and manually annotated for textual and non-textual uses of demonstratives. The translation correspondences are organized into congruent and divergent $[22,23,28]$ and adapted to observe optional and obligatory shifts in the translation. The lexical correspondences are quantified and further examined drawing on comparable data [42].

The findings suggest that the Lithuanian demonstratives fall into the categories of universal uses of demonstratives and that the Lithuanian three-way system of demonstratives shows signs of reduction to a two-way system, with the neutral (medial) demonstrative tas [this/that] occurring in complementary distribution with the distal demonstrative anas [that]. The findings reveal that the prevailing translation strategy is optional implicitation that is caused by the availability of contextual variants and semantic reinterpretation of demonstratives in the translation. The marginal obligatory shifts are associated with changes in verb complementation in the translation, demonstrative comparisons and demonstrative cleft constructions. Comparable material reveals that the Lithuanian discourse is more demonstrative than the English discourse due to an overuse of the anaphoric and recognitional neutral (medial) demonstrative tas in Lithuanian.

This type of study has implications for the investigation of deictic words in translation by demonstrating that there is greater formal equivalence in the exophoric than textual uses of demonstratives. It also carries implications for the task of unveiling a three-way system as a two-way system of demonstratives, with the neutral (medial) demonstrative showing weak signs of article usage.

This paper is organized as follows. Section 2 introduces the system of demonstratives in Lithuanian and reviews the pragmatic accounts of demonstratives in Lithuanian. Section 3 describes the methodology and explains how demonstratives were extracted and compared using triangulation methodology. The results are presented in three subsections. The first one reviews the distribution of demonstratives by function in the parallel corpus. The second discusses the main uses of demonstratives from the translational and cross-linguistic point of view. The third subsection is concerned with the results based on comparable material. The final section introduces the concluding remarks.

\section{Demonstratives in Lithuanian: Form and Function}

The basic semantic distinction between near and distant forms in Lithuanian is complemented by the neutral member tas [this/that], while the English demonstrative system expresses a simple distance contrast within a binary set. Figure 1 shows the ternary system of the Lithuanian demonstratives [2, p. 263]:

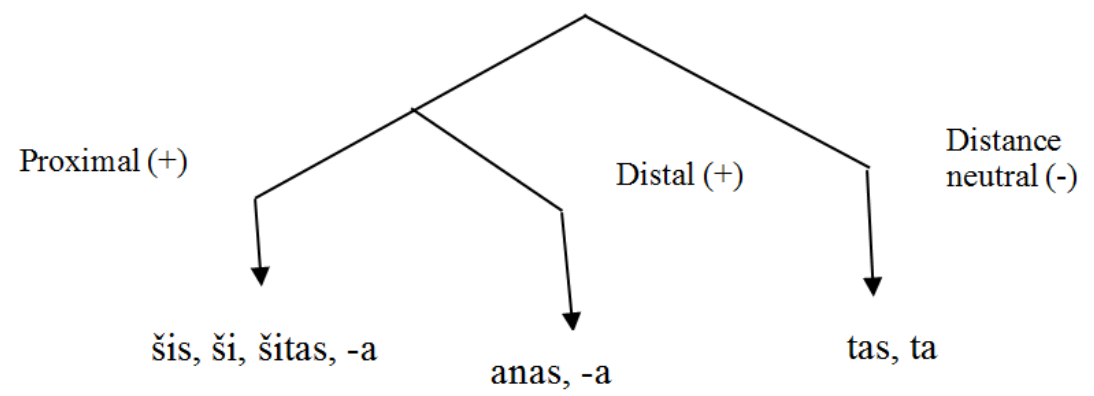

Figure 1. The system of demonstratives in Lithuanian (A Grammar of Modern Lithuanian).

The terms šis/šitas [this] and anas [that] are in contrastive distribution expressing a universal opposition between proximity and distality, while the neutral tas [this/that] is a substitute for distance-marked demonstratives [51, p. 74]. According to Rosinas [51], the neutral term adds no specific distance parameter but can be used to express proximity or distality when used alongside distance-marked demonstratives. The neutral term tas can be contrasted to šis/šitas and anas but is also used when no contrast between proximity and distance is implied [1, p. 195]. The opposition consists of elements that differ in the nature of deixis (pointing) [57, p. 139]. Valeckiene [57] associates tas with pointing to an object that is more or less distant from the speaker and terms it 'neutral deixis'.

As observed by Judžentyte [29, p. 191], in spoken Lithuanian the neutral demonstrative tas is the main distal pronoun, while the distal demonstrative anas is developing the function of specifying an object (i.e. drawing attention to 
an object and explaining its location). It is suggested that the Lithuanian system of demonstratives should be binary rather than ternary. This tendency is observed due to a limited number of occurrences of the distal demonstrative anas in spoken Lithuanian.

Demonstratives have their neuter gender forms functioning as absolute demonstratives. Absolute demonstratives possess the differential feature of proximity (šitai [it/this]) and distance neutrality (tai [it/this/that]). The opposition between absolute demonstratives is neutralized. The system of the Lithuanian demonstrative pronouns contains some facultative members or semantic variants of demonstratives with different semantic overtones, such as quality (toks [of this/that kind]) and emphatic demonstratives (tas pats [this/that same]). Special adjectival demonstratives šioks/šitoks/toks/anoks [of this/that kind] acquire the same deictic features as demonstratives proper [57, p. 139].

The communicative functions of demonstratives are subdivided into deictic and anaphoric uses in Lithuanian [50, p. 10]. Demonstratives are defined in terms of their semantic features and the distinction between proximity and distality in relation to the speaker as the deictic centre. From the semantic point of view, demonstratives perform the differential function. As defined by Rosinas [50, 51], the uses of demonstrative pronouns are distinguished on the semantic rather than pragmatic basis.

The functional features of the pronominal article tas described by Rosinas [50, 51] have affinity with the recognitional function of demonstratives. In the recognitional use, the intended referent is identified on the basis of "personalized knowledge" arising from "a common interactional history" or "shared experiences" [26, p. 233]. Any presumption of familiarity indicates that the pronoun is a demonstrative in its recognitional function rather than the pronominal article [55, p. 128]. Spoken Lithuanian shows signs of the grammaticalization of the distance-neutral demonstrative, but there is no empirical evidence in this respect.

The review of the semantic and pragmatic features of the Lithuanian demonstratives suggests that the pragmatic functions of demonstratives receive sporadic attention in the works on reference. There is the discussion that the Lithuanian system of demonstratives deserves to be reduced to a two-way system and that the neuter demonstrative is taking over most of the functions. The English demonstratives have been widely analysed from the point of view of co-referential rules and the necessary conditions underlying the textual and non-textual uses of demonstratives. The assumptions regarding such rules are rather implicit in the descriptions of the semantic characteristics of demonstratives in Lithuanian.

\section{Data and Method}

The conceptual basis for the present analysis stems from the corpus linguistic line of research into deixis from the systemic-contrastive and textual pragmatic perspective $[7,8$, $22,23,46,47]$. To discuss the results within the broader textual pragmatic explicitness/implicitness hypothesis, the study is based on a data triangulation scheme (a tripartite corpus structure) consisting of source texts in language A, target texts in language $B$, and original texts in language $B$ $[6,9,42]$. As noted by Baumgarten et al. [6, p. 188), a tripartite corpus structure enables a thorough contrastive systemic and stylistic analysis and a comparison of the communicative purposes of texts. The statistical comparison of comparable and parallel texts enables avoidance of false or biased conclusions about the use of language units in a translated and untranslated text $[9$, p. 2].

This study uses a self-compiled corpus of the works of English fiction and their translation ${ }^{1}$ into Lithuanian. Translation paradigms are used as a starting point and the most frequent items are compared in different contexts of usage [23, p. 93]. Optional and obligatory translational implicitations/explicitations are observed for determining the extent to which usage is controlled pragmatically [32, p. 15-17]. Table 1 shows the size of the parallel corpus and the size of the corpus of original ${ }^{2}$ Lithuanian fiction texts. The parallel and comparable data sets comprise extracts of 10,000 to 15,000 words from the beginning of the narrative.

Table 1. The size of the parallel corpus.

\begin{tabular}{ll}
\hline Subcorpus & No. of words \\
\hline EN ORIG & 503,735 \\
LT TRANSL & 389,139 \\
LT ORIG & 508,590 \\
Total & $1,401,464$ \\
\hline
\end{tabular}

The digitized texts were automatically aligned at the sentence level using the alignment editor InterText [58]. ParaConc [5] was used to produce descriptive statistics and for the purposes of concordance analysis. The English files were pre-tagged using the Sketch Engine part-of-speech tagger [54] for the extraction of the English demonstrative that.

The demonstratives this and that were manually annotated for textual, non-textual and other uses. References containing features of textual and non-textual (exophoric) usage were assigned to the mixed category of uses. The feature of the recoverability of the antecedent was employed to distinguish between the uses of demonstratives [10]. The features of equivalence were determined on the basis of the typological classification of translation correspondence by Johansson [28, p. 25]. A statistical and qualitative comparison of comparable texts is made as a validation procedure. The automatic search of forms in original Lithuanian was carried out by employing the AntConc [3] concordance tool.

\footnotetext{
1 Index Translationum: Unesco Culture Sector (1990-2008) [27] and The Lithuanian Association of Literary Translators (2009-2017) were used for the lists of translated modern English literature.

2 Extracted and morphologically annotated by Doc. dr. Andrius Utka (Centre of Computational Linguistics at Vytautas Magnus University) [14].
} 


\section{Results and Discussion}

This section introduces the results of functional distribution of the English demonstrative pronouns this/that and the frequencies of their translation correspondences. It also introduces and compares the results obtained from a comparable untranslated corpus of Lithuanian fiction texts.

\subsection{Frequency Distribution in a Parallel Corpus}

Table 2 presents the normalized frequencies of translation correspondences of the English demonstrative this. The English proximal demonstrative in its discourse deictic use occurred with the highest frequency, followed by exophoric symbolic and anaphoric uses.

Table 2. Functions and distribution of the proximal demonstrative 'this' in the translation.

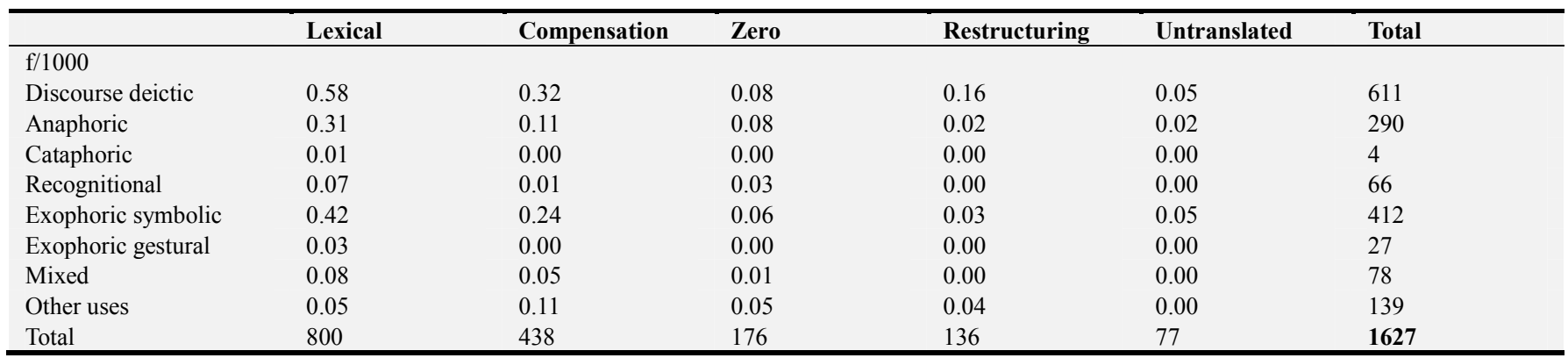

The surface structure features of fictional texts are characterized by a significant number of textual references and a smaller proportion of exophoric references. The coreferential (anaphoric) use of demonstratives is generally regarded as less typical than the other uses. The observation that this and that are mainly discourse deictic can be found in Levinson [38, p. 85]. Himmelmann [26, p. 226] points out that in non-conversational discourse the anaphoric (coreferential) use of both demonstratives is relatively infrequent. The present data conforms to the general distributional patterns of demonstrative pronouns in narrative texts in that it shows that both this and that are predominantly discourse deictic. Table 3 shows the functional distribution of the distal demonstrative that.

Table 3. Functions and distribution of the distal demonstrative 'that' in the translation.

\begin{tabular}{|c|c|c|c|c|c|c|}
\hline & Lexical & Compensation & Zero & Restructuring & Untranslated & Total \\
\hline \multicolumn{7}{|l|}{$\mathrm{f} / 1000$} \\
\hline Discourse deictic & 0.81 & 0.72 & 0.22 & 0.30 & 0.07 & 1077 \\
\hline Anaphoric & 0.17 & 0.16 & 0.03 & 0.04 & 0.01 & 213 \\
\hline Cataphoric & 0.00 & 0.00 & 0.00 & 0.00 & 0.00 & 3 \\
\hline Recognitional & 0.19 & 0.01 & 0.07 & 0.02 & 0.00 & 152 \\
\hline Exophoric symbolic & 0.26 & 0.13 & 0.07 & 0.04 & 0.02 & 278 \\
\hline Exophoric gestural & 0.05 & 0.03 & 0.02 & 0.00 & 0.00 & 61 \\
\hline Other uses & 0.06 & 0.14 & 0.04 & 0.15 & 0.01 & 213 \\
\hline Total & 790 & 628 & 244 & 296 & 73 & 2031 \\
\hline
\end{tabular}

As noted by Botley and McEnery [11, p. 26], regardless of the interpersonal context or the genre, the non-proximal that is more common than this in reference to propositions. The analysed examples indicate that there is a less pronounced distinction between the anaphoric and discourse deictic usage of the English demonstrative this. Its distal counterpart is more marked in this respect.

The demonstrative this was translated by alternative means in $51 \%$ of the examples, while the distal that was rendered by different means in $61 \%$ of the examples. $40 \%$ is considered a high degree of non-correspondence in the translation of time deictic words [23, p. 93-94]. The data show that the resulting high degree of non-correspondence in the translation of spatial deixis is due to the optional implicitation procedure, as the usage of demonstratives is largely pragmatically controlled and reflects language-specific preferences in textbuilding and narrative stylistics. Obligatory implicitations/explicitations occurred in $7 \%(n=259)$ of the examples, resulting from the translation of comparative and demonstrative cleft constructions and changes in verb complementation in the translation of transitive constructions.

\subsection{Types of Reference}

This section presents the distributional results of the translation correspondences of the English demonstratives this and that. It examines the patterns emerging from the translation of nominal and adnominal demonstratives in the discourse deictic, anaphoric, exophoric and recognitional functions.

\subsubsection{Discourse Deictic Reference}

The discourse deictic function is coded by the distance-neutral pronominal tai $(44 \%, \mathrm{n}=131)$ in Lithuanian (Table 4). The demonstrative tai [it/this/that] performs the generalising and presentative function. The distinction between this and that in discourse deixis is based on a detachment strategy, where the distal demonstrative can express an external perspective towards a proposition [34, p. 90]. A similar distinction can be observed with adnominal discourse deictic demonstratives in Lithuanian, 
where the usage of tas is motivated by a shift to an addressee orientation in the narrative.

Table 4. Lexical correspondences of 'this' in the discourse deictic function.

\begin{tabular}{|c|c|c|c|c|}
\hline & \multicolumn{2}{|l|}{ LT nominal } & \multicolumn{2}{|l|}{ LT adnominal } \\
\hline & Correspondence & $\mathbf{N}$ & Correspondence & $\mathbf{N}$ \\
\hline \multirow{4}{*}{ EN nominal this } & tai [it/this/that] & 131 & ši/s [this] & 11 \\
\hline & šitai [it/this] & 10 & ta/s [that] & 9 \\
\hline & visa tai [all it/this/that] & 8 & šita/s [this] & 4 \\
\hline & ši/s [this] & 1 & & \\
\hline \multirow{3}{*}{$\mathrm{EN}$ adnominal this } & tai $[$ it/this/that] & 8 & ši/s [this] & 76 \\
\hline & šitas [this] & 1 & ta/s [that] & 30 \\
\hline & $\mathrm{ta} / \mathrm{s}[$ that $]$ & 1 & šita/s [this] & 6 \\
\hline Total & & 160 & & 136 \\
\hline
\end{tabular}

The lexical correspondences of the distal that show that tas is more common in expressing a detached perspective to propositions than the proximal šis (Table 5). The loglikelihood test indicates a significant difference between tas as a correspondence of the discourse deictic this and that $(\mathrm{LL}=-7.72)$. This suggests that šis and tas are not fully interchangeable but may signal that one type of expression is the preferred one rather than obligatory [44, p. 219].

Table 5. Lexical correspondences of 'that' in the discourse deictic function.

\begin{tabular}{|c|c|c|c|c|}
\hline & \multicolumn{2}{|l|}{ LT nominal } & \multicolumn{2}{|l|}{ LT adnominal } \\
\hline & Correspondence & $\mathbf{N}$ & Correspondence & $\mathbf{N}$ \\
\hline \multirow{4}{*}{ EN nominal that } & tai [it/this/that] & 306 & $\mathrm{ta} / \mathrm{s}$ [that] & 7 \\
\hline & šitai [it/this] & 11 & ši/s [this] & 6 \\
\hline & $\mathrm{ta} / \mathrm{s}$ [that] & 7 & šita/s [this] & 3 \\
\hline & šitas [this] & 1 & & \\
\hline \multirow{2}{*}{ EN adnominal that } & tai [it/this/that] & 7 & $\mathrm{ta} / \mathrm{s}$ [that] & 37 \\
\hline & & & šitas [this] & 3 \\
\hline Total & & 336 & & 73 \\
\hline
\end{tabular}

Studies on the difference between proximal and distal demonstratives often rely on the distance-based explanation, which is applicable in clearly contrastive contexts and the situational usage of demonstratives. The detachment strategy resulting in a change of perspective towards a proposition can be criticised on the grounds that conceptually it evolves from Lakoff's [36] emotional deixis, which is often treated as an arbitrary classification. According to Maes [40, p. 172173], the distinction between proximal and distal demonstratives should be explained in terms of the reference domain based on interactional relations between the speaker/writer and the addressee. Research on the Dutch, Finnish, Estonian and Spanish demonstratives stresses the role of the speaker and hearer and their perception of the situation as the determining factors in the choice of demonstratives [15, 18, 31, 37]. A distal demonstrative is preferred when the addressee becomes more important in the discourse setting.

There is a considerable scope for optional implicitation in rendering discourse deictic demonstratives to Lithuanian. The nominal discourse deictic this corresponds to the pronominal adverbial taip [in this manner], as exemplified by (1). boy!"

(1) $<\ldots>$ "My Lord, I do not say this out of concern for the $<\ldots>$ - Valdove, taip sakau ne todèl, kad vaikèzo gailéčiau! The pronominal adverb taip/šitaip serves to convey an evaluative component of meaning. The grammaticality of the proposition is not distorted if taip is replaced by the neutral demonstrative tai or a demonstrative noun phrase. Obviously, not all transitive slots fall clearly into one category in the translation and the usage of taip may depend on the semantic content of the verb.

The nominal discourse deictic this also corresponds to the nominal generalizer viskas [all] in Lithuanian as a result of optional implicitation (example 2). However, the pragmatic informativeness of the sentence in the sense of the Gricean expectation of unambiguous reference is reduced due to the less explicit relationship with the textual referent.

(2) As a tick, as a lord, as a newt. Must write this down before $<\ldots>$

Kaip gaidys, kaip pédas, kaip dūmas. Turiu spèti viska užrašyti, kol <...>

The quality demonstrative toks [of this kind] is a common correspondence of the adnominal discourse deictic this. As a special adjectival demonstrative, toks denotes a definite quality of a thing or phenomenon [2, 56]. As noted by Noergård-Soerensen [45, p. 130], the semantic representation of a noun phrase containing a quality demonstrative represents the assertion of the truth of a general rule. The choice of the type of a demonstrative ultimately depends on the speaker and the fact that a text fulfills an educational purpose, where rules of general value are formulated, as in (3). 
(3) Maybe he was getting old. He knew where this thought had come from, <...>

Gal jis seno. Jis suprato, iš kur tokia mintis, $<\ldots>$

The demonstrative adverb čia [here] is also closely parallel with the discourse deictic function of the nominal this and that. The adverb čia establishes a discourse deictic link to the preceding portion of text by appearing in the presentative construction, as illustrated in (4), and is replaceable by the nominal demonstrative tai or a demonstrative noun phrase.

(4) Find that spacer and we find the thieves! $\langle\ldots>$ And that was just an imaginary example.

Surasim žvaigždèlaivị, surasim ir nusikaltèlius. $<\ldots>$ Juk čia tik sąlyginis pavyzdys.

Non-congruent optional equivalents of the discourse deictic demonstratives include the quality demonstrative toks, manner adverbial taip, place adverbial ćia and the generalizer viskas. There are no significant differences between the frequencies of these discourse deictics in the translation of the proximal and distal English demonstratives, except a significant underuse of taip/šitaip as correspondences of this ( $L L=-13.36)$, which resulted from a greater number of examples with the omissible that after transitive verbs.

\subsubsection{Anaphoric Reference}

The unmarked anaphoric strategy in English presupposes the use of the personal pronoun, while variation from the unmarked strategy signals a new rhetorical stage [21, p. 627]. English uses a demonstrative noun phrase to reintroduce the antecedent after consecutive use of personal pronouns [20, p. 19]. The usage of an anaphoric demonstrative may or may not coincide in Lithuanian in such reference chains. As reported by Kunz [35, p. 390], anaphoric demonstratives are employed for closer and more distant antecedents and preferences rather than generalizations can be noted. Coreferential chains are also subject to a shine-through effect in translation. The lexical correspondences of the anaphoric this in Lithuanian are shown in table 6.

Table 6. Lexical correspondences of 'this' in the anaphoric function.

\begin{tabular}{lllll}
\hline & LT nominal & \multicolumn{3}{l}{ LT adnominal } \\
\cline { 2 - 5 } & Correspondence & $\mathbf{N}$ & Correspondence & N \\
\hline EN & šita/s [this] & 3 & ši/s [this] & 6 \\
nominal & tai [it/this/that] & 2 & ta/s [that] & 2 \\
this & ši/s [this] & 2 & & \\
& toji [this/that] & 1 & & 56 \\
& tai [it/this/that] & 4 & ši/s [this] & 49 \\
EN & & & ta/s [that] & 22 \\
adnominal & & & šita/s [this] & 12 \\
this & & & toji/tasai [this one/that one] & 12 \\
& & & šitoji [this one] & 2 \\
Total & & 12 & & 149 \\
\hline
\end{tabular}

Table 7 shows the lexical correspondences of the English distal demonstrative in the anaphoric function. The distributions of correspondences confirm the general situation of making an apparent distinction between the proximal and distal demonstratives in the Lithuanian translated texts. The examples illustrate that the demonstrative tas corresponds to the English distal demonstrative.

Table 7. Lexical correspondences of 'that' in the anaphoric function.

\begin{tabular}{lllll}
\hline & LT nominal & \multicolumn{2}{l}{ LT adnominal } & \\
\cline { 2 - 5 } & Correspondence & $\mathbf{N}$ & Correspondence & N \\
\hline EN & tai [it/this/that] & 6 & ta/s [that] & 4 \\
nominal & šita/s [this] & 2 & ši/s [this] & 2 \\
that & & & toji [this one/that one] & 1 \\
EN & tai [it/this/that] & 11 & ta/s [that] & 44 \\
adnominal & ta/s [that] & 1 & ši/s [this] & 7 \\
that & šita/s [this] & 1 & šita/s [this] & 3 \\
& & & ana/s [that] & 2 \\
& & & toji [this one/that one] & 2 \\
Total & & 21 & & 65 \\
\hline
\end{tabular}

The distribution of deictic space is similar in English and Lithuanian, as tas is used to refer to the hearer's space and thus corresponds to the English distal deictic pointing to the hearer's sphere [cf. 13, p. 296]. Some studies report systematic changes in the viewing position in the narrative through the use of distal and proximal demonstratives [e.g. 43]. This data shows that the distribution of the speaker's space and the hearer's space is retained and reinterpretation is due to decisions at the conceptual level.

Non-congruent correspondences suggest that demonstrative anaphoric marking as a signal for closure of the anaphoric sequence is less constrained in Lithuanian. The ongoing anaphoric reference in the Lithuanian examples is signalled by personal pronouns or nouns. In Lithuanian, a demonstrative noun phrase in anaphoric usage may be redundant, particularly if the emphatic or attitudinal element is absent. Immediate anaphora favours the personal pronoun in Lithuanian, where English may prefer a demonstrative description even with thematically prominent immediate antecedents.

\subsubsection{Exophoric Reference}

Table 8 summarizes the lexical correspondences of this in the exophoric gestural usage. In the gestural usage, the contextual variants are more restricted. They are limited to the demonstrative particles va/stai [here] and the demonstrative adverb čia [here] in contexts of optionality.

Table 8. Lexical correspondences of the exophoric gestural 'this'.

\begin{tabular}{|c|c|c|c|c|}
\hline & \multicolumn{2}{|l|}{ LT nominal } & \multicolumn{2}{|l|}{ LT adnominal } \\
\hline & Correspondence & $\mathbf{N}$ & Correspondence & $\mathbf{N}$ \\
\hline EN nominal this & & & & \\
\hline EN adnominal & šita/s [this] & 4 & šita/s [this] & 9 \\
\hline this & ta/s [that] & 2 & ši/s [this] & 4 \\
\hline Total adnominal & & 6 & & 13 \\
\hline
\end{tabular}

Table 9 shows the distribution of the lexical correspondences of the exophoric gestural that. The distribution of tas as a translation correspondence of the English distal demonstrative indicates that in both languages the proximal/distal dichotomy determines the distribution of corresponding demonstratives [cf. 34, p. 54]. The distinction becomes obvious in dialogue where the demonstrative tas is used in real space and functions as a marker of physical or psychological distance. As noted by Judžentyte [29, p. 191; 
30, p. 78], the demonstrative tas tends to lexicalize physical distance in conversational Lithuanian.

Table 9. Lexical correspondences of the exophoric gestural 'that'.

\begin{tabular}{lllll}
\hline & LT nominal & \multicolumn{3}{l}{ LT adnominal } \\
\cline { 2 - 5 } & Correspondence & $\mathbf{N}$ & Correspondence & $\mathbf{N}$ \\
\hline EN nominal that & tai [it/this/that] & 6 & šita/s [this] & 2 \\
EN adnominal & ši/s [this] & 1 & ta/s [that] & 12 \\
that & šita/s [this] & 1 & ši/s [this] & 3 \\
Total adnominal & ana/s [that] & 1 & šita/s [this] & 1 \\
\hline
\end{tabular}

Tables 10 and 11 summarize the lexical correspondences of the English demonstratives in the exophoric symbolic usage, which indicate an analogous distinction between the proximal šis and the distal tas in Lithuanian.

Table 10. Lexical correspondences of the exophoric symbolic 'this'.

\begin{tabular}{lllll}
\hline & LT nominal & \multicolumn{3}{l}{ LT adnominal } \\
\cline { 2 - 5 } & Correspondence & $\mathbf{N}$ & Correspondence & $\mathbf{N}$ \\
\hline \multirow{4}{*}{ EN nominal this } & tai [it/this/that] & 9 & ši/s [this] & 4 \\
& ši/s [this] & 2 & ta/s [that] & 1 \\
& šitai [it/this] & 1 & šita/s [this] & 1 \\
& ta/s [that] & 1 & & \\
EN adnominal & šita/s [this] & 3 & ši/s [this] & 136 \\
this & & & šita/s [this] & 34 \\
& & & ta/s [that] & 19 \\
Total adnominal & & & ana/s [that] & 1 \\
\hline
\end{tabular}

The exophoric symbolic usage has a wider range of contextual variants than exophoric gestural usage not due to the basic semantics of demonstratives but to an extended range of referents reflected in time and place expressions. Entities outside the text are subdivided into time deictics, place deictics, and person deictics [52, p. 340].

Table 11. Lexical correspondences of the exophoric symbolic 'that'.

\begin{tabular}{lllll}
\hline & LT nominal & \multicolumn{3}{l}{ LT adnominal } \\
\cline { 2 - 5 } & Correspondence & $\mathbf{N}$ & Correspondence & $\mathbf{N}$ \\
\hline EN nominal that & $\begin{array}{l}\text { tai [it/this/that] } \\
\text { šitai [it/this] }\end{array}$ & 10 & ta/s [that] & 2 \\
EN adnominal & 1 & & \\
that & & & ta/s [that] & 110 \\
Total adnominal [this] & 6 \\
\hline
\end{tabular}

Typical place deictic usage is inherently related to the proximal pronoun šis in the adnominal position and cooccurrence with nouns of abstract meaning, as in the sequence this +place. The most typical contextual variant is the demonstrative adverb čia characterized by features of close proximity and familiarity with the place of reference. Temporal deictic expressions are characterized by a wider range of non-congruent correspondences and are used in contexts of optionality with compound adverbs (e.g. širyt [this morning]) and the generalized temporal adverb dabar [now] as their correspondences.

These contextual variants occur as optional translational implicitations and are subject to pragmatic control with no genuine contextual effects. As noted by Powell [48, p. 117118], pure indexicals such as now and here are truthconditionally equivalent with the complex demonstratives this time and this place, which are less colloquial and more sufficient in determining the extent of reference. Where a full demonstrative noun phrase reinforces spatial reference, a pure indexical indicates a property of being a time. Example (5) illustrates a context of optionality for the symbolic usage.

(5) He laughed again, and this time I knew he was laughing at me.

Jis vèl nusijuokè, bet dabar supratau, kad juokiasi iš manęs.

The analysis of the concordances of exophoric uses suggests that non-textual usage is associated with a greater distinction between the demonstratives šis and tas than either anaphoric or discourse deictic uses. The exophoric usage, as a prototypical usage of demonstratives, reflects a high degree of correspondence in both languages. This is caused by the occurrence of time and place deictic expressions that find their full formal equivalence in Lithuanian.

\subsubsection{Recognitional Reference}

In the recognitional usage, demonstrative noun phrases contain the distal demonstrative, which is motivated by the fact that the special status of the distal demonstrative derives from experience shared in the past. In contexts of current identification, the proximal demonstrative this can occur in the recognitional use [56, p. 1510]. Table 12 shows the translation correspondences of the proximal demonstrative this in the recognitional usage.

Table 12. Translation correspondences of the recognitional 'this'.

\begin{tabular}{|c|c|c|c|c|}
\hline & \multicolumn{2}{|l|}{ LT nominal } & \multicolumn{2}{|l|}{ LT adnominal } \\
\hline & Correspondence & $\mathbf{N}$ & Correspondence & $\mathbf{N}$ \\
\hline \multirow{5}{*}{$\begin{array}{l}\text { EN adnominal } \\
\text { this }\end{array}$} & & & $\mathrm{ta} / \mathrm{s}$ [that] & 30 \\
\hline & & & $\varnothing^{*}$ & 20 \\
\hline & & & ši/s [this] & 4 \\
\hline & & & šita/s [this] & 4 \\
\hline & & & other & 8 \\
\hline Total & & 0 & & 66 \\
\hline
\end{tabular}

*Zero correspondence or omission.

The translation correspondences of the English distal recognitional demonstrative confirm that it is commonly matched by the demonstrative tas in Lithuanian, as summarized in Table 13.

Table 13. Translation correspondences of the recognitional 'that'.

\begin{tabular}{|c|c|c|c|c|}
\hline & \multicolumn{2}{|l|}{ LT nominal } & \multicolumn{2}{|l|}{ LT adnominal } \\
\hline & Correspondence & $\mathbf{N}$ & Correspondence & $\mathbf{N}$ \\
\hline $\mathrm{EN}$ & šita/s [this] & 1 & $\mathrm{ta} / \mathrm{s}$ [that] & 90 \\
\hline adnominal & tai [it/this/that] & 1 & $\varnothing^{*}$ & 37 \\
\hline that & & & $\begin{array}{l}\text { tasai/toji [this one/that one] } \\
\text { other }\end{array}$ & $\begin{array}{l}3 \\
9\end{array}$ \\
\hline Total & & 2 & & 139 \\
\hline
\end{tabular}

*Zero correspondence or omission.

The Lithuanian demonstrative tas occurs in similar 
contexts as the recognitional demonstratives in English. It occurs in constructions with the post-modifying relative clause that functions as a formal device for reference confirmation in the recognitional usage, as in (6).

(6) "That little rock you're so curious about may have seen Alaric sack Rome" < ..>

- Tas akmenèlis, kuris tau taip rūpi, galbūt regèjo, kaip Alarikas nusiaube Roma, <...>

The other examples are references to "peripheral participants" in the narrative that are not distinguished by any formal recognitional device [26, p. 230]. The recognitional demonstrative co-occurs with proper names in contexts where the knowledge about narrative participants is reactivated in the process of current identification. Recognitional meaning indexes the speaker's/writer's position and seeks recognizability [12, p. 271].

A considerable proportion of zero correspondences show that the recognitional aspect of meaning is either absent or considered redundant in cases when referent confirmation is achieved through the presence of a post-modifying clause, pronominal adjective and other modifying words. The presence of the pronominal adjective mažoji [that/the little], as illustrated by (7), invokes recognition of the intended referent.

(7) The next year had seen the arrival of Jason, and three years after that blond little Paige had been born.

Kitais metais gimè Džeisonas, o dar po trejų metu mažoji šviesiaplaukè Peidže.

A substantial number of non-congruent correspondences is not motivated grammatically but by a tendency to normalize through optional implicitation by omitting the recognitional component in the noun phrase or choosing the pronominal adjective to evoke a familiar referent.

\subsubsection{Comparable Data Results}

The distribution of demonstratives in a comparable corpus of the Lithuanian fiction reveals a higher frequency of demonstrative usage (Table 14). Comparable material indicates that they are more pervasive in original Lithuanian than in original English texts. The demonstrative tas $(68 \%$, $\mathrm{n}=4025$ ) is the dominating type of demonstrative in the data, followed by šis $(21 \%, \mathrm{n}=1228)$, šitas $(5 \%, \quad \mathrm{n}=296)$, toji/tasai/sitoji $(3 \%, \mathrm{n}=206)$ and anas $(3 \%, \mathrm{n}=161)$.

Table 14. Distribution of demonstratives in EN-orig. and LT-orig.

\begin{tabular}{|c|c|c|c|c|c|c|c|c|}
\hline Corpus & $\mathbf{N}$ & $\begin{array}{l}\text { Absolute } \\
\text { frequency }^{3}\end{array}$ & f/1000 & $\begin{array}{l}\text { LL (1 } \\
\text { d.f.) }\end{array}$ & $\begin{array}{l}\mathbf{p} \\
\text { value }\end{array}$ & $\begin{array}{l}\text { Bayes } \\
\text { Factor }\end{array}$ & $\begin{array}{l}\text { Effect } \\
\text { Size }\end{array}$ & LogRatio \\
\hline $\begin{array}{l}\text { EN- } \\
\text { orig. } \\
\text { LT- } \\
\text { orig. }\end{array}$ & $\begin{array}{l}503, \\
735 \\
508, \\
590\end{array}$ & 4259 & 11,63 & $\begin{array}{l}255 \\
39\end{array}$ & $\mathrm{p}<0,05$ & 241,56 & $\begin{array}{l}0, \\
00003\end{array}$ & 0.46 \\
\hline
\end{tabular}

These distributions are in line with those based on translation data, which generally confirms a significant overuse of the neutral (medial) demonstrative tas. Tas was

3 Singular and plural forms are included. The result for singular forms $(\mathrm{LL}=112,23$, $\log$ Ratio $=0.34)$ is overlapping. the predominant correspondence in the recognitional usage. The translation data also showed that tas is common in time and place expressions with reference to the past. The neutral (medial) demonstrative is commonly associated with the introduction of referents that are not textualized, i.e., they are used to establish new referents in the discourse [4, p. 31]. This raises the question of what uses of tas are typical in the original fictional discourse, whether it is chiefly used in contexts where the referent is not present in the situation of an utterance, and whether its usage departs from deictic properties. Comparable material reveals that tas is most widely employed as an adnominal demonstrative $(n=3054)$ to an anaphoric noun phrase.

The concordances for the singular demonstrative tas in the nominative case $(n=793)$ show that its anaphoric usage is more common $\left(47 \%, \mathrm{nf}^{4}=0.73\right)$ than recognitional $(15 \%$, $\mathrm{nf}=0.23)$, discourse deictic $(14 \%, \mathrm{nf}=0.21)$, exophoric $(13 \%$, $\mathrm{nf}=0.19)$, mixed $(2 \%, \mathrm{nf}=0.02)$, cataphoric $(1 \%, \mathrm{nf}=0.01)$, and other usage $(8 \%, \mathrm{nf}=0.13)$. The concordances for tas in the accusative $(n=808)$ confirm the prevalence of the anaphoric usage $(33 \%, \mathrm{nf}=0.52)$, followed by exophoric $(20 \%, \quad n f=0.31)$, discourse deictic $(19 \%, \quad n f=0.30)$, recognitional $(18 \%, \mathrm{nf}=0.28)$, mixed $(3 \%, \mathrm{nf}=0.05)$, cataphoric $(2 \%, \mathrm{nf}=0.02)$, and other usage $(5 \%, \mathrm{nf}=0.07)$.

In English, anaphoric demonstratives are used to reintroduce important discourse topics in co-referential chains. When demonstratives are used in immediate anaphora, they are used to immediately reintroduce an important topic in story telling [26, p. 229]. Anaphoric demonstratives refer to "discourse participants that are contrastive, emphatic and somewhat unexpected" by signalling shifts in the focus of attention [16, p. 96-113]. As shown by Wolter [59, p. 19], semantically unique descriptions can acquire properties of demonstrative descriptions (e.g. that sun) with resulting emotive effects. The most important role of demonstratives is discourse organizational and their functions contribute to the development of discourse.

Comparable material indicates that in Lithuanian the anaphoric adnominal tas may show features of article substitution in associative anaphora, but such examples are marginal (20 out of 1601). Tas is common in immediate anaphora, when the antecedent is introduced in the preceding clause, and also when the anaphoric chain is relatively short. However, there is not much regularity in the usage of tas in less accessible (less immediate) anaphora where its articlelike functions could be present. Tas is mostly used optionally to evoke an emphatic meaning and focus the reader's attention on the dynamics of participants in the narrative.

Comparable material supplements the observations regarding the distal demonstrative anas. As a marginally used demonstrative, it is not reserved for a particular type of reference but shows a preference for exophoric symbolic usage in reference to past events (e.g. anais laikais [in those times]). There is a collocational preference for anas to co-

4 Normalized frequency per 1000 words. 
appear with temporal and locative nouns when a contrast between the present time and/or place is evoked.

The distinction between tas and anas suggests subtle stylistic preferences on the part of the speaker/writer. Such differences arise from the need to create a contrast and instruct the hearer to choose an appropriate referent [53, p. 152]. As noted by Scott [53], when the choice between demonstratives is marginal, it is the contrast effect itself that is relevant. However, the contrast effect when both tas and anas are possible is difficult to measure as both occur in contexts allowing the speaker/writer to shift the referent to the domain that is further away from the speaker.

Both tas and anas occur in contexts of shared private knowledge and reintroduce hearer-old information in the narrative. However, anas serves to identify and distinguish an entity or a group with the resulting specifying effect (e.g. Tai gal kaip anuos? Iš Palemono? [Maybe like those? From Palemonas?]). The distal demonstrative anas serves a specific function of resolving ambiguity in the presence of two propositions or two antecedents. It refers to a further preceding proposition or antecedent with the resulting specifying effect.

\subsubsection{Cross-linguistic Similarities and Differences}

The translation and the original material show that the textual functions of demonstratives prevail over non-textual uses in narrative texts. Demonstratives with a noun phrase or textual antecedent are more frequent than non-anaphoric demonstratives [11, 41, 49]. The correspondence of the neutral (medial) demonstrative tas to the English distal demonstrative that indicates that the Lithuanian system of demonstratives tends to be binary rather than ternary.

However, the distribution for different pragmatic functions in original Lithuanian shows that demonstratives are more typical in the anaphoric $(\mathrm{nf}=1.68)$ and recognitional functions $(\mathrm{nf}=0.57)$ than their counterparts this/that in the anaphoric $(\mathrm{nf}=0.99)$ and recognitional $(\mathrm{nf}=0.43)$ uses with a statistically significant result. These differences result from the high frequency distribution of the neutral (medial) demonstrative tas in Lithuanian.

Comparable material reveals certain preferences for the Lithuanian demonstratives. The demonstrative tas is pervasive as an optional indicator of referent identity in anaphoric adnominal usage and is a typical recognitional deictic. The nominal demonstrative $\check{s} i s$ is pervasive in immediate anaphora as a substitute for personal reference. The distal anas is most typical in exophoric time and place expressions and its discourse deictic usage is reserved for pointing to further preceding textual referents. Tas is the most recurrent demonstrative and is used anaphorically as a focus device for maintaining current relevance of topics. Its articlelike usage arising from associative anaphora with generic nouns is marginal.

In the textual functions, the usage of tas is motivated by interactional rules between the speaker/writer and addressee. Interactional or social rules are understood as spheres of attention between the speaker and addressee [13, 18, 19, 37].
In Laury [37, p. 59], it is shown that the neuter member of the system defines the addressee's sphere, the proximal demonstrative displays the understanding that a referent is within the speaker's sphere and is optionally within the addressee's sphere, while the distal member places the referent outside the speaker's sphere and defines the addressee's sphere. As pointed out in Halliday and Matthiessen, [21, p. 631], the English proximal demonstrative this is in some way or other treated in the basic deictic sense 'near' the speaker, while the 'remote' that is treated as more remote or from the listener's point of view. This suggests that the distance-based view and the view based on speaker roles should be combined in the analysis of the uses of demonstratives.

\section{Conclusion}

The purpose of this paper was to examine the pragmatic functions of the Lithuanian demonstrative pronouns by situating the analysis within the typological classification of universal uses of demonstratives. It also set the objective to evaluate the textual pragmatic implicitness/explicitness of original Lithuanian fiction texts and measure the extent to which the usage of deictic words is a result of text-building strategies and stylistic preferences, as opposed to systemic differences between English and Lithuanian. Translation correspondences were used as a basis for comparison and translation effects were verified in comparable original texts.

The usage of demonstratives in Lithuanian conforms to the universally established categories of the pragmatic uses of demonstratives (gestural, symbolic, anaphoric, cataphoric, discourse deictic and recognitional). The translation correspondences reveal that the Lithuanian three-way system of demonstratives shows signs of reduction to a two-way system, as there is a significant overlap between the neutral (medial) demonstrative and the English distal demonstrative. Comparable data confirms a complementary distribution for the Lithuanian neutral (medial) demonstrative and the marginally used distal demonstrative.

The prevailing translational strategy of optional implicitation shows that the usage of demonstratives is pragmatically motivated and reflects common text-building and stylistic preferences in Lithuanian. While lexical correspondences prevail in prototypical deictic uses of demonstratives, the textual uses of demonstratives are influenced by the availability of their contextual variants in Lithuanian.

A comparison of original texts reveals greater textual pragmatic explicitness of original Lithuanian texts, compared to their English counterparts. This distributional difference arises from the high frequency of the neutral (medial) demonstrative in Lithuanian, which functions as an optional indicator of identification in anaphoric and recognitional uses.

The present paper has practical and theoretical significance for translation studies, as deixis is recognized as a problematic area in translation theory and practice. There is a 
notion that deictic words are disregarded and omitted in translated texts. It is often argued that the translation of deixis is highly subjective and dependent on subtle changes in textual coherence. The present paper has argued that the translation of deictic words is pragmatically controlled and that it is also function dependent.

\section{References}

[1] Ambrazas, V. (ed). 1997. Lithuanian Grammar. Vilnius: Baltos lankos.

[2] Ambrazas, V. (ed). 2006. Dabartines lietuviu kalbos gramatika. [A Grammar of Modern Lithuanian]. Vilnius: Mokslo ir enciklopedijų leidykla.

[3] Anthony, L. 2014. AntConc (Version 3.4.3). Tokyo: Waseda University.

[4] Balpinar, M. 2019. Demonstratives and Grammaticalization: A Perspective from Modern Turkish. London: Routledge.

[5] Barlow, M. 2008. ParaConc and Parallel Corpora in Contrastive and Translation Studies. Houston: Athelstan Publications.

[6] Baumgarten, N., Meyer, B., Özçetin, D. 2008. Explicitness in Translation and Interpreting. A Review and Some Empirical Evidence (of an Elusive Concept). Across Languages and $\begin{array}{lrrrr}\text { Cultures, } & 9 & (2): & 177-203 .\end{array}$ https://doi.org/10.1556/Acr.9.2008.2.2.

[7] Becher, V. 2010. Differences in the Use of Deictic Expressions in English and German texts. Linguistics 48 (6): 1309-1342. https://doi.org/10.1515/ling.2010.042.

[8] Becher, V. 2011. Explicitation and Implicitation in Translation. A Corpus-based Study of English-German and German-English Translations of Business Texts. $\mathrm{PhD}$ thesis, University of Hamburg.

[9] Bernardini, S. 2011. Monolingual Comparable Corpora and Parallel Corpora in the Search for Features of Translated Language. SYNAPS: A Journal of Professional Communication, 26: 2-13. http://hdl.handle.net/11250/2393975.

[10] Botley, S. 2000. Corpora and Discourse Anaphora: Using Corpus Evidence to Test Theoretical Claims. PhD thesis, Lancaster University.

[11] Botley, S., McEnery, T. 2001. Demonstratives in English: A Corpus-based Study. Journal of English Linguistics, 29 (1): 7 33. https://doi.org/10.1177\%2F00754240122005170.

[12] Consten, M., Averintseva-Klisch, M. 2012. Tentative Reference Acts? 'Recognitional Demonstratives' as Means of Suggesting Mutual Knowledge - or Overriding a Lack of It, Research in Language, 10 (3): 257-277. https://doi.org/10.2478/v10015-011-0033-x.

[13] Cuenca, M. J. 2020. Pragmatics and Text Linguistics. In Manual of Catalan Linguistics, J. A. Argenter and J. Lüdtke (eds), 287-310. Berlin: Walter de Gruyter. https://doi.org/10.1515/9783110450408.

[14] Dabartines lietuviu kalbos tekstynas [Corpus of the Contemporary Lithuanian Language]. http://corpus.vdu.lt/lt/.
[15] Da Milano, F. 2007. Demonstratives in the Languages of Europe. In Europe and the Mediterranean as Linguistic Areas: Convergencies from a Historical and Typological Perspective, P. Ramat and E. Roma (eds), 25-48. Amsterdam: John Benjamins. https://doi.org/10.1075/slcs.88.04mil.

[16] Diessel, H. 1999. Demonstratives: Form, Function and Grammaticalization. Amsterdam: John Benjamins. https://doi.org/10.1075/tsl.42.

[17] Diessel, H. 2014. Demonstratives, Frames of Reference, and Semantic Universals of Space. Language and Linguistics Compass, 8 (3): $116-132$. https://doi.org/10.1111/lnc3.12066.

[18] Etelämäki, M. 2009. The Finnish Demonstrative Pronouns in Light of Interaction. Journal of Pragmatics, 41 (1): 25-46. https://doi.org/10.1016/j.pragma.2008.09.005.

[19] Ewing, M. 2014. Pragmatic Uses of Demonstratives in Cirebon Javanese Conversation. In Deixis and Spatial Expressions in Languages of Indonesia (NUSA 56), A. Jukes (ed), 47-63. http://hdl.handle.net/10108/77645.

[20] Fox, B. 1987. Discourse Structure and Anaphora. Cambridge: Cambridge University Press. https://doi.org/10.1017/CBO9780511627767.

[21] Halliday, M., Matthiessen, C. 2014. Halliday's Introduction to Functional Grammar. London: Routledge. https://doi.org/10.4324/9780203431269.

[22] Hasselgård, H. 2004. Spatial Linking in English and Norwegian. In Translation and Corpora, K. Aijmer and H. Hasselgård (eds), 163-188. Göteborg: Acta Universitatis Gothoburgensis.

[23] Hasselgård, H. 2006. "Not now" - on Non-correspondence between the Cognate Adverbs now and nå. Pragmatic Markers in Contrast, 2: 93-114.

[24] House, J. 1997. Translation Quality Assessment. A Model Revisited. Tübingen: Narr.

[25] House, J. 2015. Translation Quality Assessment: Past and Present. New York: Routledge. https://doi.org/10.4324/9781315752839.

[26] Himmelmann, N. P. 1996. Demonstratives in Narrative Discourse: A Taxonomy of Universal Uses. In Studies in Anaphora, B. Fox (ed), 205-254. Amsterdam: John Benjamins. https://doi.org/10.1075/ts1.33.08him.

[27] Index Translationum - World Bibliography of Translation. http://www.unesco.org/xtrans/.

[28] Johansson, S. 2007. Seeing through Multilingual Corpora: On the Use of Corpora in Contrastive Studies. Amsterdam: John Benjamins. https://doi.org/10.1075/scl.26.

[29] Judžentyte, G. 2017. Spatial Deixis in Lithuanian: Demonstrative Pronouns. In Language: Meaning and Form 8. Grammatical and Lexical Variance in Language System, A. Kalnača and I. Lokmane (eds), 173-193. Rīga: LU Akadēmiskais apgāds.

[30] Judžentytė-Šinkūnienè, G. 2018. The System of the Demonstrative Pronouns Provided in the Grammar of Modern Lithuanian: Analysis of Traditions. In Valoda: nozīme un forma 9. Gramatika un pragmatika, A. Kalnača and I. Lokmane (eds), 68-79. Rīga: LU Akadēmiskais apgāds. 
[31] Jungbluth, K. 2003. Deictics in the Conversational Dyad. In Deictic Conceptualisation of Space, Time and Person, F. Lenz (ed), 13-40. Amsterdam: John Benjamins. https://doi.org/10.1075/pbns.112.

[32] Klaudy, K., Károly, K. 2005. Implicitation in Translation: Empirical Evidence for Operational Asymmetry in Translation. Across Languages and Cultures, 6 (1): 13-28. https://doi.org/10.1556/Acr.6.2005.1.2.

[33] Kranich, S. 2016. Contrastive Pragmatics and Translation. Amsterdam: John Benjamins. https://doi.org/10.1075/pbns.261.

[34] Kryk, B. 1987. On Deixis in English and Polish: The Role of Demonstrative Pronouns. Frankfurt am Main: Verlag Peter Lang.

[35] Kunz, K. A. 2010. Variation in English and German Nominal Coreference - A Study of Political Essays. Frankfurt am Main: Verlag Peter Lang.

[36] Lakoff, R. 1974. Remarks on This and That. Papers from the Tenth Regional Meeting of the Chicago Linguistic Society, 10, 345-356.

[37] Laury, R. 1997. Demonstratives in Interaction. The Emergence of a Definite Article in Finnish. Amsterdam: John Benjamins. https://doi.org/10.1075/sidag.7.

[38] Levinson, S. C. 1983. Pragmatics. Cambridge: Cambridge University Press.

[39] Levinson, S. C. 2004. Deixis. In The Handbook of Pragmatics, L. R. Horn and G. Ward (eds), 97-121. Oxford: Blackwell Publishing.

[40] Maes, A. 1991. Nominal Anaphors and the Coherence of Discourse. Belgium: Tilburg University.

[41] Maes, A. 1996. Nominal Anaphors, Markedness, and the Coherence of Discourse. Leuven: Peeters.

[42] Malamatidou, S. 2017. Corpus Triangulation: Combining Data and Methods in Corpus-Based Translation Studies. London: Routledge. https://doi.org/10.4324/9781315669595.

[43] Mason, I., Şerban, A. 2003. Deixis as an Interactive Feature in Literary Translations from Romanian into English. Target, 15 (2): 269-294. https://doi.org/10.1075/target.15.2.04mas.

[44] Matras, Y., Bolkestein, M. 2006. Deixis and Anaphora: Some Case Studies. In Pragmatic Organisation of Discourse in the Languages of Europe, G. B. Marcia and L. Schwartz (eds), 215-254. Berlin: Walter De Gruyter. https://doi.org/10.1515/9783110892222.

[45] Noergård-Soerensen, J. 1992. Coherence Theory: The Case of Russian. Berlin: Mouton de Gruyter. https://doi.org/10.1515/9783110858686.

[46] Pavesi, M. 2013. This and That in the Language of Film.
Dubbing: A Corpus-based Analysis. Meta, 58 (1): 103-133. https://doi.org/10.7202/1023812ar.

[47] Pavesi, M. 2015. The Translation of Conversation and Film Dubbing as a Discovery Procedure: Evidence from Demonstratives. In Language across Languages - New Perspectives on Translation, E. Miola and P. Ramat (eds), 143-172. Cambridge Scholars Publishing.

[48] Powell, G. 2010. Language, Thought and Reference. Hampshire: Palgrave Macmillan.

[49] Ribera, C. J., Cuenca, M. J. 2013. Use and Translation of Demonstratives in Fiction: A Contrastive Approach (EnglishCatalan). Catalan Review: International Journal of Catalan Culture, 27: 27-49. https://doi.org/10.3828/CATR.27.1.27.

[50] Rosinas, A. 1996. Lietuviu bendrinès kalbos ịvardžiai: funkcijos ir semantika. [Pronouns in Standard Lithuanian: Functions and Semantics]. Vilnius: Mokslo ir Enciklopediju Leidykla.

[51] Rosinas, A. 2009. Baltu kalbu juvardžiu semantinè ir morfologine struktūra: sinchronija ir diachronija. [Semantic and Morphological Structure of Pronouns in the Baltic Languages: Synchrony and Diachrony]. Vilnius: Mokslo ir enciklopedijų leidybos institutas.

[52] Rühlemann, C., O’Donnell, M. B. 2015. Deixis. In Corpus Pragmatics: A Handbook, K. Aijmer and C. Rühlemann (eds), 331-359. Cambridge: Cambridge University Press. https://doi.org/10.1017/CBO9781139057493.

[53] Scott, K. 2019. Referring Expressions, Pragmatics, and Style: Reference and Beyond. Cambridge: Cambridge University Press. https://doi.org/10.1017/9781316822845.

[54] The https://www.sketchengine.eu/my_keywords/tag/.

Engine.

[55] Spraunienè, B. 2011. Apibrèžtumo žymèjimas lietuviu kalboje lyginant su danu ir kitomis artikelinemis kalbomis. [The Marking of Definiteness in Lithuanian. Against the Background of Danish and other Article Languages]. PhD thesis, Vilnius University.

[56] Stirling, L., Huddleston, R. 2002. Deixis and Anaphora. In The Cambridge Grammar of the English Language, R. Huddleston and G. K. Pullum (eds), 1449-1564. Cambridge: Cambridge University Press. https://doi.org/10.1017/9781316423530.018.

[57] Valeckienè, A. 1998. Funkciné lietuviu kalbos gramatika. [Functional Grammar of Lithuanian]. Vilnius: Mokslo ir enciklopedijų leidybos institutas.

[58] Vondřička, P. 2016. InterText Editor v1.5 Comprehensive guide. Institute of the Czech National Corpus, Charles University.

[59] Wolter, L. 2003. Demonstratives, Definite Descriptions, and Definiteness. University of California at Santa Cruz. 